\title{
Groundwater geochemistry observations in littoral caves of Mallorca (western Mediterranean): implications for deposition of phreatic overgrowths on speleothems
}

\author{
Liana M. Boop ${ }^{1 *}$, Bogdan P. Onac ${ }^{1}$, Jonathan G. Wynn ${ }^{1}$, Joan J. Fornós ${ }^{2}$, \\ Marta Rodríguez-Homar ${ }^{2}$, and Antoni Merino ${ }^{3}$ \\ ${ }^{1}$ School of Geosciences, University of South Florida, 4202 E. Fowler Ave., NES 107, Tampa, FL 33620, USA \\ ${ }^{2}$ Departament de Ciències de la Terra, Universitat de les Illes Balears, Cra. Valldemossa, km. 7.5, Palma de Mallorca, 07122, Spain \\ ${ }^{3}$ Federació Balear d'Espeleologia, Grup Espeleològic de Llubí, Illes Balears, Spain
}

\begin{abstract}
Phreatic overgrowths on speleothems (POS) precipitate at the air-water interface in the littoral caves of Mallorca, Spain. Mainly composed of calcite, aragonite POS are also observed in specific locations. To characterize the geochemical environment of the brackish upper water column, water samples and salinity values were collected from water profiles $(0-2.9 \mathrm{~m})$ in April 2012 and March 2013 near aragonite POS in Cova des Pas de Vallgornera and calcite POS in Coves del Drac (hereafter, Vallgornera and Drac). Degassing of $\mathrm{CO}_{2}$ from the water was evidenced by the existence of lower dissolved inorganic carbon (DIC) concentration and enriched $\delta^{13} C_{D I C}$ values in a thin surface layer (the uppermost $0.4 \mathrm{~m}$ ), which was observed in both profiles from Drac. This process is facilitated by the efficient exchange of cave air with the atmosphere, creating a $\mathrm{CO}_{2}$ partial pressure $\left(\mathrm{CCO}_{2}\right)$ disparity between the cave water and air, resulting in the precipitation of calcite $\mathrm{POS}$ as $\mathrm{CO}_{2}$ degasses from the water. The degassed upper layer was not observed in either profile from Vallgornera, suggesting that less efficient cave ventilation restricts outgassing of $\mathrm{CO}_{2}$, which also results in accumulation of $\mathrm{CO}_{2}$ in the cave atmosphere. The presence of an existing uncorroded POS horizon, as well as higher concentrations and large amplitude fluctuations of cave air $p \mathrm{CO}_{2}$, may indicate that aragonite POS deposition is currently episodic in Vallgornera. Ion concentration data from monthly water samples collected in each cave between October 2012 and March 2013 indicate higher Mg:Ca, Sr:Ca, Ba:Ca and Sr:Mg ratios in Vallgornera. Salinity alone does not appear to be a viable proxy for ions that may promote aragonite precipitation or inhibit calcite precipitation. Instead, these ions may be contributed by more intense bedrock weathering or deep groundwater flow.
\end{abstract}

Keywords: $\quad$ subaqueous calcite and aragonite; stable isotopes; $\mathrm{CO}_{2}$ degassing; $\mathrm{Mg}$ :Ca ratio; littoral karst; Balearic Islands

Received 15 October 2013; Revised 15 April 2014; Accepted 22 April 2014

Citation: $\quad$ Boop L.M., Onac B.P., Wynn J.G., Fornós J.J., Rodríguez-Homar M. and Merino A., 2014. Groundwater geochemistry observations in littoral caves of Mallorca (western Mediterranean): implications for deposition of phreatic overgrowths on speleothems. International Journal of Speleology, 43 (2), 193-203. Tampa, FL (USA) ISSN 0392-6672 http://dx.doi.org/10.5038/1827-806X.43.2.7

\section{INTRODUCTION}

A variety of carbonate speleothems are deposited as $\mathrm{CO}_{2}$ degasses from a solution containing calcium and dissolved inorganic carbon, thus triggering supersaturation and deposition of $\mathrm{CaCO}_{3}$ (Fairchild et al., 2006). Since the beginning of phreatic overgrowths on speleothem (POS) investigations in Mallorca, $\mathrm{CO}_{2}$ degassing from the cave water has been documented to cause POS precipitation (Pomar et al., 1976, 1979; Csoma et al., 2006). This is in accordance with the greater understanding of the development of floating cave rafts and shelfstones, which form at the surface of cave pools by $\mathrm{CO}_{2}$ degassing to the cave air (Hill \& Forti, 1997).

POS are widespread in the littoral caves of Mallorca, where the level of the Mediterranean Sea controls the water table. POS are precipitated at the air-water interface in brackish water onto preexisting supports, including previously deposited vadose speleothems or cave walls. POS are ideal proxies for sea level changes, as they can be precisely and accurately dated using the U/Th method, and constrain former high or low sea level stands with sub-meter precision (Ginés \& 
Ginés, 1972, 2007; Tuccimei et al., 2007; Dorale et al., 2010). Calcite is the dominant mineral in the POS precipitated during the Holocene [Marine Isotope Stage (MIS) 1], while the $\mathrm{CaCO}_{3}$ polymorph aragonite is less common. A notable exception is Cova des Pas de Vallgornera (Vallgornera), where POS preserved at the present water level are aragonite. However, both calcite and aragonite POS corresponding to previous high- and lowstands are also documented in this cave, suggesting that the recent geochemical environment is different compared to time periods when calcite precipitated. In Coves del Drac (Drac), current POS are calcite, but aragonite is also identified in older encrustations. For comparative purposes, data from Drac are presented in this paper to contextualize observations from Vallgornera.

Collecting geochemical data and samples from profiles of the upper groundwater column allows an evaluation of interactions that take place at the airwater interface, where POS precipitate. Profiles are commonly used to understand stratified bodies of water in karst features, where the freshwater lens, halocline, and marine groundwater can be delineated, such as in cenotes and blue holes (Pohlman, 2011; Martin et al., 2012). Although the deepest accessible water body was selected at each site, neither location was deep enough to sample through the halocline. In contrast to the typical Ghyben-Herzberg coastal aquifer model, a distinct freshwater lens is absent in these caves. Instead, a transition zone between the freshand seawater endmembers is present with brackish water found in the upper column. Conductivity, temperature, and depth data collected by divers with handheld sensors indicate that there are multiple layers of increasing salinity with depth before the sharp transition to marine groundwater, commonly regarded as the halocline (Gràcia et al., 2011a, b). This study investigated the upper $2 \mathrm{~m}$ or more of water columns in Vallgornera and Drac (Fig. 1).

The goal of this paper is to explain the mineralogical differences observed in Mallorca's POS, assessing the following hypotheses using monthly air and water samples and water column profiles at each site:

1. In general, precipitation of carbonate POS is controlled by $\mathrm{CO}_{2}$ degassing at the air/water interface. Without a sufficient difference between the partial pressure of $\mathrm{CO}_{2}\left(p \mathrm{CO}_{2}\right)$ of the water and air, precipitation will not occur. The rate of degassing is determined by the magnitude of the disparity between the $\mathrm{pCO}_{2}$ of the cave water and cave atmosphere.
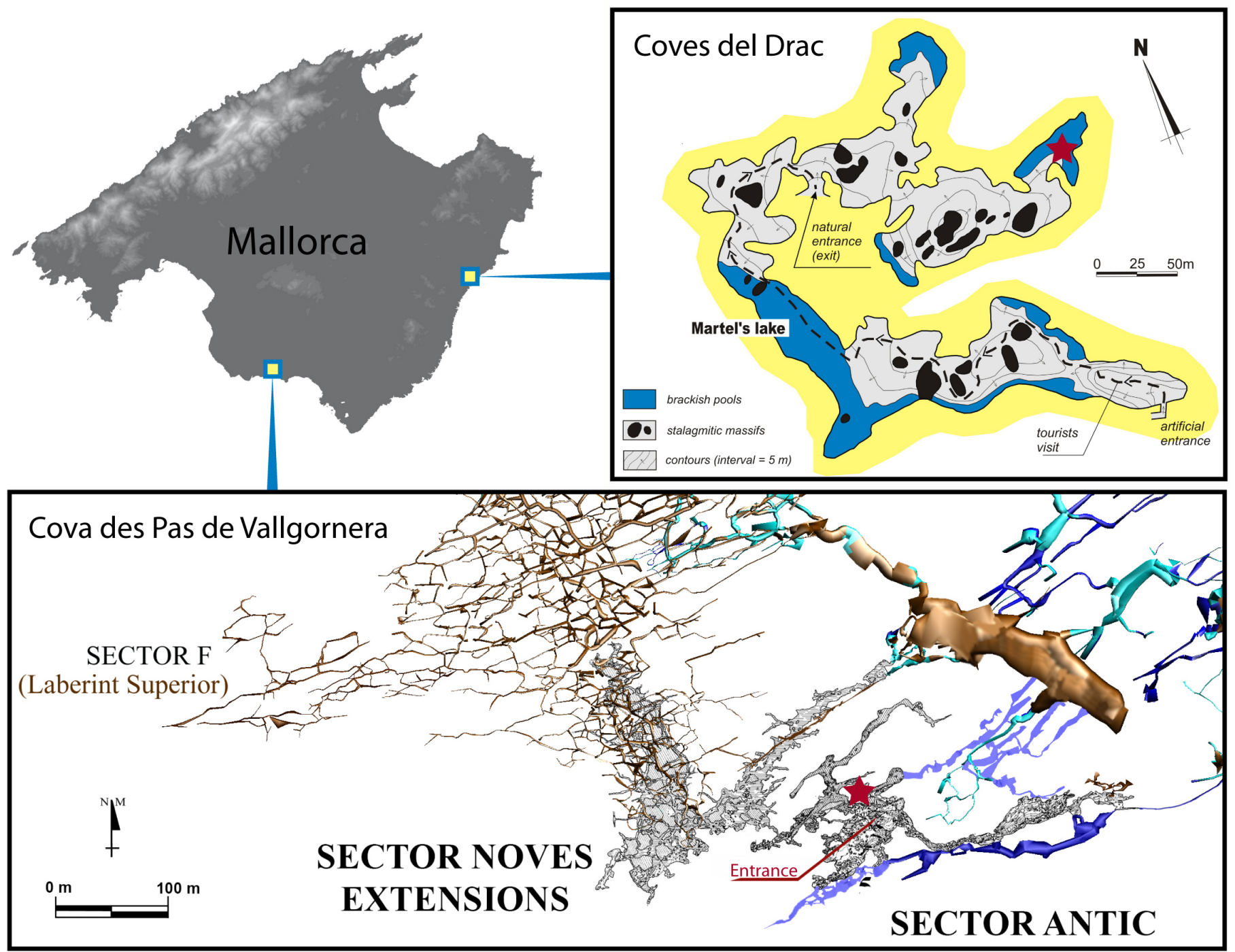

Fig. 1. Locations of the investigated caves in Mallorca and maps of Drac (after Ginés \& Ginés, 2007) and a section of Vallgornera (after Merino et al., 2011) with the locations of the water profiles and monthly samples indicated by stars $(\star)$. 
2. In Mallorca's brackish cave waters, dense aragonite crystals making up the POS precipitate under low rates of $\mathrm{CO}_{2}$ degassing, whereas porous and/or dendritic calcite POS are deposited when $\mathrm{CO}_{2}$ outgases at faster rates as documented elsewhere by other studies (Frisia et al., 2000, 2002; Niedermayr et al., 2013).

3. Precipitation of aragonite is controlled by higher $\mathrm{Sr}: \mathrm{Ca}, \mathrm{Mg}: \mathrm{Ca}$, and/or $\mathrm{Ba}: \mathrm{Ca}$ ratios, which inhibit calcite precipitation (Berner, 1975; McMillan et al., 2005; De ChoudensSánchez \& González, 2009; Niedermayr et al., 2013). In the studied caves, these inhibitors may derive from seawater, bedrock, or deep groundwater flow.

4. Field observations suggest changes in salinity affect the kinetics of carbonate-solutions interactions, influencing the mineralogy of the carbonate phase (Folk, 1974; Zhong \& Mucci, 1989). In the two investigated caves, salinity alone is not a suitable proxy for the mineralogy of carbonate encrustations or the rate of calcite and aragonite precipitation.

\section{STUDY AREA}

Located in the western Mediterranean Sea, Mallorca is the largest island of the Balearic Archipelago. The climate is typical of the western Mediterranean, with hot, dry summers, and mild winters. The average annual temperature is $16.6^{\circ} \mathrm{C}$, and rainfall on Mallorca is highly variable, ranging from 300 to $1,400 \mathrm{~mm}$ (Guijarro, 1995). Most of its littoral caves are located along the south and east coasts in Upper Miocene reef limestones (Ginés et al., 2014). Here, at the mixing zone between fresh and marine groundwater, cave passages host water with a range of salinities.

Vallgornera is on Mallorca's southern coast (Fig. 1 ), and is the longest known cave on the island with more than $74 \mathrm{~km}$ of mapped passage (Merino et al., 2014). The area above the cave includes a vacant hotel, residential buildings, and undeveloped land. The only known entrance to Vallgornera was opened in 1968 when excavation for the hotel septic system intersected a large chamber. As part of its Natura 2000 status, access to Vallgornera is only granted for scientific or exploration purposes. Since cavers traveling deeper into the cave avoid the study location, only minor effects of human visitation are expected.

Drac is located on the eastern coast (Fig. 1) near the village of Porto Cristo. Displaying typical mixing zone characteristics (Ginés \& Ginés, 2007), the mapped vadose extent of Drac is $2,359 \mathrm{~m}$, with an additional $600 \mathrm{~m}$ of submerged passages accessed by cave divers (Gràcia et al., 2007, 2011b). The cave was first opened for tourism around 1898 (Ginés \& Ginés, 2011), and is currently the most visited cave in Europe (Robledo \& Durán, 2010). The area above the cave is developed with cafés, shops, parking lots, and other infrastructure to support the local tourism industry. Tourists enter the cave through an artificial entrance, walking through well-decorated cave passages until they arrive at a large chamber where they sit for a 30-minute classical music concert performed from boats that navigate upon the underground Lake Martel. Tourists exit the cave through the natural collapse entrance. The tourist infrastructure has likely modified the cave environment in terms of ventilation, temperature, atmospheric gas concentration, and the introduction of non-native materials. However, the study area and the tourist route are on separate branches of the cave, so less touristic impacts are expected at the monitored site. The study area is located along a historic tour route that is at present exclusively accessed for scientific purposes. Calcite rafts are typically observed on the water surface at the study site. Active bat populations and guano deposits are present near the study area.

\section{METHODS}

Geochemical data and samples were collected from profiles in Vallgornera and Drac in April 2012 and March 2013 as scheduled fieldwork permitted. The deepest accessible body of water was selected in each cave, and the profiles were collected at the same location during the return visit. Profiles ranged to a maximum depth of $2.9 \mathrm{~m}$; the extent of each profile was limited by the water level, which fluctuates within the tidal range of $\pm 25 \mathrm{~cm}$ and is influenced by atmospheric pressure and wind stress (GómezPujol et al., 2007). Salinity was assessed using a HI 9828 Multiparameter Meter (Hanna Instruments) and is presented in Practical Salinity Units (PSU; Millero et al., 2008) with manufacturer-specified accuracy of $\pm 2 \%$ and precision of 0.01 PSU.

During the April 2012 site visits, water samples (analyses discussed below) were collected through disposable low-density polyethylene (LDPE) tubing attached to a hand pump. The March 2013 water samples were collected using a 1-liter capacity LaMotte Water Sampler that was simultaneously lowered with the HI 9828 probe. Samples were taken at 0.5 $\mathrm{m}$ intervals starting at the surface after the salinity reading was stabilized and recorded. In the April 2012 Drac profile the second sample was recovered at 0.4 $\mathrm{m}$, and subsequent samples were obtained at 0.5 $\mathrm{m}$ intervals. Samples were refrigerated at $4^{\circ} \mathrm{C}$ until analysis.

Monthly cave air temperature and $p \mathrm{CO}_{2}$ data is presented between October 2012 and March 2013. Values for both parameters were extracted from longterm monitoring records using $\mathrm{CO} 2$ meter.com $\mathrm{K} 33-$ ELG (accuracy $\pm 0.4^{\circ} \mathrm{C}$ and $\pm 30 \mathrm{ppm}$; precision $\pm 0.1^{\circ} \mathrm{C}$ and $\pm 20 \mathrm{ppm}$ ). Because relative humidity at each site approached $100 \%$ and the sensor operating range only extends to $95 \%$, the instruments were placed upon Zorb-It desiccant packages within a plastic box with holes drilled in the sides. Non-dispersive infrared (NDIR) sensors measured $\mathrm{CO}_{2}$ concentration and data were corrected using in-cave barometric pressure measurements to calculate $p \mathrm{CO}_{2}$ according to Spötl et al. (2005). Cave barometric pressure was recorded using In-Situ Inc. BaroTROLL data loggers and is reported in $\mathrm{hPa}$ (accuracy $\pm 1.5 \mathrm{hPa}$; precision $\pm 0.075 \mathrm{hPa}$ ). 
Monthly surface water physical parameters $(\mathrm{pH}$, temperature, and salinity) were measured between October 2012 and March 2013 using the HI 9828 probe (accuracy $\pm 0.02 \mathrm{pH}, \pm 0.15^{\circ} \mathrm{C}$, and $\pm 2 \%$; precision $\pm 0.01 \mathrm{pH}, \pm 0.01^{\circ} \mathrm{C}$, and $\left.0.01 \mathrm{PSU}\right)$. A water sample was stored at $4^{\circ} \mathrm{C}$ and analyzed within 6 hours of collection for total alkalinity, sulfate, and total hardness. Total alkalinity was assessed using a Hach digital titrator (method 8230). Sulfate and total hardness were measured using an Orbeco-Hellige portable colorimeter (model 975MP). The saturation indices (SI) of calcite and aragonite and water $\mathrm{pCO}_{2}$ were computed using CO2calc version 1.2 (Robbins et al., 2010) and input parameters of water salinity, temperature, total alkalinity, and air $\mathrm{pCO}_{2}$.

Additionally, monthly water samples were collected into pre-cleaned $250 \mathrm{~mL}$ Nalgene containers with no headspace and stored at $4^{\circ} \mathrm{C}$ until analysis for $\mathrm{Ca}, \mathrm{Mg}$, $\mathrm{Sr}$, and $\mathrm{Ba}$ concentrations. Analyses were completed at the University of South Florida School of Geosciences (USF-SG) Center for Geochemical Analysis using a Perkin-Elmer ELAN DRC II Quadrupole Inductively Coupled Plasma Mass Spectrometer (ICP-MS). Percent error was determined based on replicate analysis of standard reference material NIST 1640a-1 throughout the run and varies by element. $\mathrm{Ca}$ and $\mathrm{Mg}$ are reported in $\mathrm{ppm}$, whereas $\mathrm{Sr}$ and $\mathrm{Ba}$ are reported in $\mathrm{ppb}$.

Stable isotope measurements are expressed in standard $\delta$ (delta)-notation:

$$
\delta(\%)=\left(\frac{R_{s p l}-R_{s t d}}{R_{s t d}}\right) \times 1,000
$$

where $R_{\text {spl }}$ and $\mathrm{R}_{\text {std }}$ represent the measured ${ }^{18} \mathrm{O} /{ }^{16} \mathrm{O}$ or ${ }^{13} \mathrm{C} /{ }^{12} \mathrm{C}$ ratios in the sample and the standard, respectively. Isotopic and dissolved inorganic carbon (DIC) concentration analyses were conducted at the USF-SG Stable Isotope Lab using a Thermo Delta V 3 keV Isotope Ratio Mass Spectrometer (IRMS) equipped with a Thermo Gasbench II device and autosampler.

Water samples for $\delta^{18} \mathrm{O}$ measurements were collected in pre-cleaned $250 \mathrm{~mL}$ Nalgene containers with no headspace, whereas those for $\delta^{13} \mathrm{C}_{\mathrm{DIC}}$ and [DIC] were collected according to the methods of Révész \& Doctor (2014) using $5 \mathrm{mg}$ copper sulfate as a bactericide. For each $\delta^{18} \mathrm{O}$ analysis, $200 \mu \mathrm{L}$ of sample was pipetted into a $12 \mathrm{~mL}$ vial. Samples were flushed with a mixture of $3 \% \mathrm{CO}_{2}$ in $\mathrm{He}$ and then stored at $20^{\circ} \mathrm{C}$ for 24 hours to promote complete ${ }^{18} \mathrm{O}$ equilibration between $\mathrm{CO}_{2}$ in the vial headspace and the sample water. Equilibrated $\mathrm{CO}_{2(\mathrm{~g})}$ was then analyzed on the IRMS; $\delta^{18} \mathrm{O}$ values are reported with $0.1 \%$ o precision relative to the $\mathrm{V}-\mathrm{SMOW}$ scale.

To determine the $\delta^{13} \mathrm{C}_{\mathrm{DIC}}$ of each sample, $1 \mathrm{~mL}$ of sample was injected into $12 \mathrm{~mL}$ vials that contained $1 \mathrm{~mL}$ of $85 \%$ phosphoric acid and were flushed with $\mathrm{He}_{(\mathrm{g})}$. The acidified sample was allowed to equilibrate at $25^{\circ} \mathrm{C}$ for 24 hours. The isotopic composition of $\mathrm{CO}_{2}$ produced from the reaction of DIC and phosphoric acid was analyzed on the IRMS and $\delta^{13} C_{\text {DIC }}$ values are reported with $0.1 \%$ precision relative to the $\mathrm{V}$-PDB standard. Internal [DIC] standards were created using a range of weights of sodium bicarbonate $(0.025 \mathrm{mg}$ to $1 \mathrm{mg}$ ) in $12 \mathrm{~mL}$ vials, which were then flushed with
$\mathrm{He}_{(\mathrm{g})}$. One $\mathrm{mL}$ of DIC-free water was then injected into each vial, followed by $1 \mathrm{~mL}$ of $85 \%$ phosphoric acid. The concentration standards were allowed to react at $25^{\circ} \mathrm{C}$ for 24 hours, and [DIC] of water was analyzed simultaneously with $\delta^{13} \mathrm{C}_{\mathrm{DIC}}$. The April 2012 [DIC] results are reported in $\mu \mathrm{mol} / \mathrm{kg}$. The March 2013 [DIC] data are omitted as the samples were compromised.

\section{RESULTS}

\section{Salinity}

Salinity increases with depth in both caves (Fig. 2, Table 1). Overall, salinity is higher in Drac than Vallgornera (Table 2). In both caves, the April 2012 profile displays higher salinity than the March 2013 profile at every comparable depth with the exception of the surface value. These trends are evident despite the more restricted salinity range of the Vallgornera March 2013 profile due to lower water level in the cave compared to the April 2012 sampling.

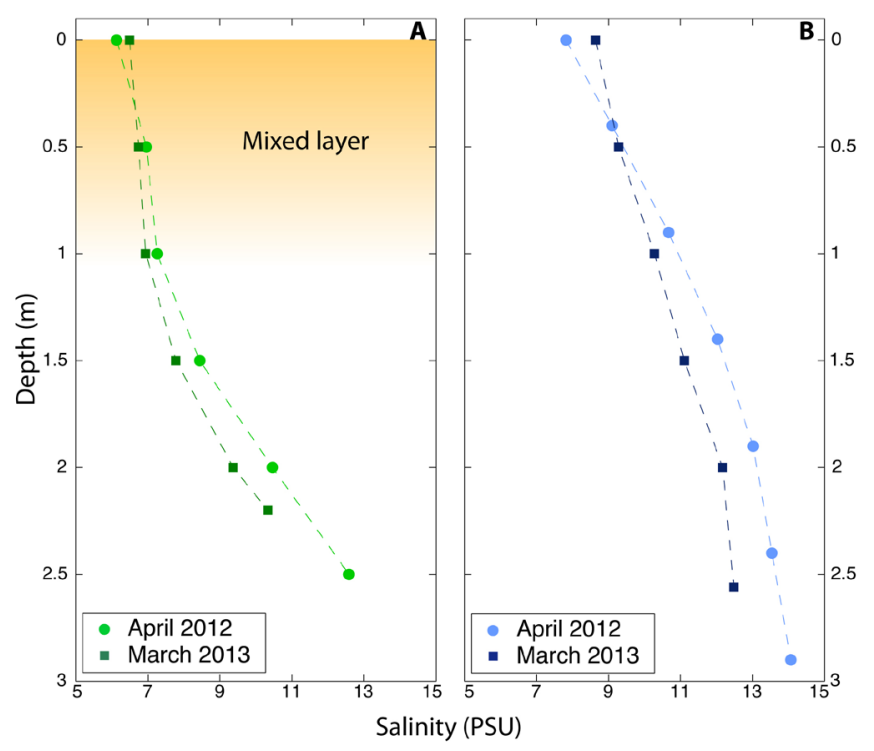

Fig. 2. Salinity profiles collected from Vallgornera (A) and Drac (B).

Table 1. Values from the April 2012 and March 2013 profiles in Vallgornera and Drac. The surface value is $0.0 \mathrm{~m}$. Maximum depths are indicated by the last value of each profile. Blank cells indicate that values were not recorded for this interval.

\begin{tabular}{|c|c|c|c|c|c|c|c|c|}
\hline \multirow{2}{*}{ Cave } & \multirow[t]{2}{*}{$\begin{array}{l}\text { Depth } \\
(\mathrm{m})\end{array}$} & \multicolumn{2}{|c|}{$\begin{array}{l}\text { Salinity } \\
\text { (PSU) }\end{array}$} & \multicolumn{2}{|c|}{$\begin{array}{c}\delta^{18} \mathrm{O} \\
(\%, \text { VSMOW) }\end{array}$} & \multicolumn{2}{|c|}{$\begin{array}{c}\delta^{13} C_{\text {DIC }} \\
(\%, \text { VPDB) }\end{array}$} & \multirow{2}{*}{$\begin{array}{c}\begin{array}{c}{[\mathrm{DIC}]} \\
(\mu \mathrm{mol} / \mathrm{kg})\end{array} \\
\text { April } \\
2012\end{array}$} \\
\hline & & $\begin{array}{l}\text { April } \\
2012\end{array}$ & $\begin{array}{c}\text { March } \\
2013\end{array}$ & $\begin{array}{l}\text { April } \\
2012\end{array}$ & $\begin{array}{c}\text { March } \\
2013\end{array}$ & $\begin{array}{l}\text { April } \\
2012\end{array}$ & $\begin{array}{c}\text { March } \\
2013\end{array}$ & \\
\hline \multirow{7}{*}{ 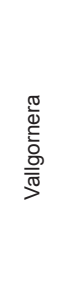 } & Surface & 6.13 & 6.49 & -4.5 & -4.3 & -10.4 & -10.4 & $4,854.3$ \\
\hline & 0.5 & 6.96 & 6.74 & -4.4 & -4.1 & -9.2 & -10.0 & $5,012.5$ \\
\hline & 1.0 & 7.26 & 6.94 & -4.3 & -4.1 & -9.7 & -10.0 & $4,962.5$ \\
\hline & 1.5 & 8.44 & 7.78 & -4.1 & -4.0 & -10.4 & -9.7 & $5,378.9$ \\
\hline & 2.0 & 10.46 & 9.37 & -4.3 & -4.0 & -9.2 & -9.8 & $4,721.1$ \\
\hline & 2.2 & & 10.33 & & -3.6 & & -9.2 & \\
\hline & 2.5 & 12.59 & & -3.7 & & -8.9 & & $4,438.0$ \\
\hline \multirow{7}{*}{ 这 } & Surface & 7.82 & 8.64 & -4.3 & -3.7 & -8.5 & -9.3 & $5,212.3$ \\
\hline & 0.5 & 9.10 & 9.28 & -4.1 & -3.6 & -11.2 & -10.6 & $7,985.0$ \\
\hline & 1.0 & 10.67 & 10.28 & -4.0 & -3.6 & -11.4 & -10.4 & $8,393.0$ \\
\hline & 1.5 & 12.03 & 11.11 & -3.8 & -3.4 & -11.1 & -10.7 & $7,277.3$ \\
\hline & 2.0 & 13.02 & 12.17 & -3.8 & -3.4 & -11.5 & -10.7 & $7,851.8$ \\
\hline & 2.5 & 13.54 & 12.48 & -3.7 & -3.3 & -11.0 & -11.1 & $7,818.5$ \\
\hline & 2.9 & 14.07 & & -3.6 & & -11.1 & & $7,052.5$ \\
\hline
\end{tabular}


Due to differences in the salinity gradient, the profiles in Vallgornera display a concave shape, with greater increases in salinity with depth (Fig. 2A). The shape of the Drac profiles opposes that of Vallgornera, with a convex shape created by the greatest increases in salinity at shallower depths (Fig. 2B).

\section{Oxygen isotopic composition}

$\delta^{18} \mathrm{O}$ values increased with depth in both caves, and were lower in Vallgornera samples than those from Drac at comparable depths (Fig. 3, Table 1). In both Vallgornera profiles, the $\delta^{18} \mathrm{O}$-depth gradient is disrupted by a distinct shift toward lower values at $2 \mathrm{~m}$ (Fig. 3A). The March $2013 \delta^{18} \mathrm{O}$ profile from both caves is offset toward higher values; in Vallgornera, this offset ranges between 0.1 and $0.4 \%$, while it is larger in Drac (between 0.4 and 0.7\%o).

\section{Carbon isotopic composition (DIC)}

Though limited by the $2.5 \mathrm{~m}$ depth of the pool, it appears that there is a trend toward higher $\delta^{13} \mathrm{C}_{\mathrm{DIC}}$ values with depth in the April 2012 Vallgornera profile (Fig. 4A, Table 1). $\delta^{13} \mathrm{C}_{\text {DIC }}$ values of the March 2013 profile increase with depth and display less variance than the April 2012 profile.

A distinct shape is observed in both Drac profiles, where surface $\delta^{13} \mathrm{C}_{\text {DIC }}$ values are positively offset, with no evident trend observed between $0.5 \mathrm{~m}$ and the bottom of either profile (Fig. 4B). The surface offset (calculated by subtracting the surface value from the average of the deeper values) was 2.7 and 1.4\%o in the April 2012 and March 2013 profiles, respectively.

\section{DIC concentration}

The April 2012 Vallgornera [DIC] generally decreased with depth, though variation is evident throughout the profile (Fig. 5, Table 1). Overall, [DIC] values vary by $3,180.7 \mu \mathrm{mol} / \mathrm{kg}$ in Drac, over three times the range observed in Vallgornera $(940.9 \mu \mathrm{mol} / \mathrm{kg})$. This is due largely to the $2,772.7 \mu \mathrm{mol} / \mathrm{kg}$ offset of the surface value from deeper values, which are higher in concentration.

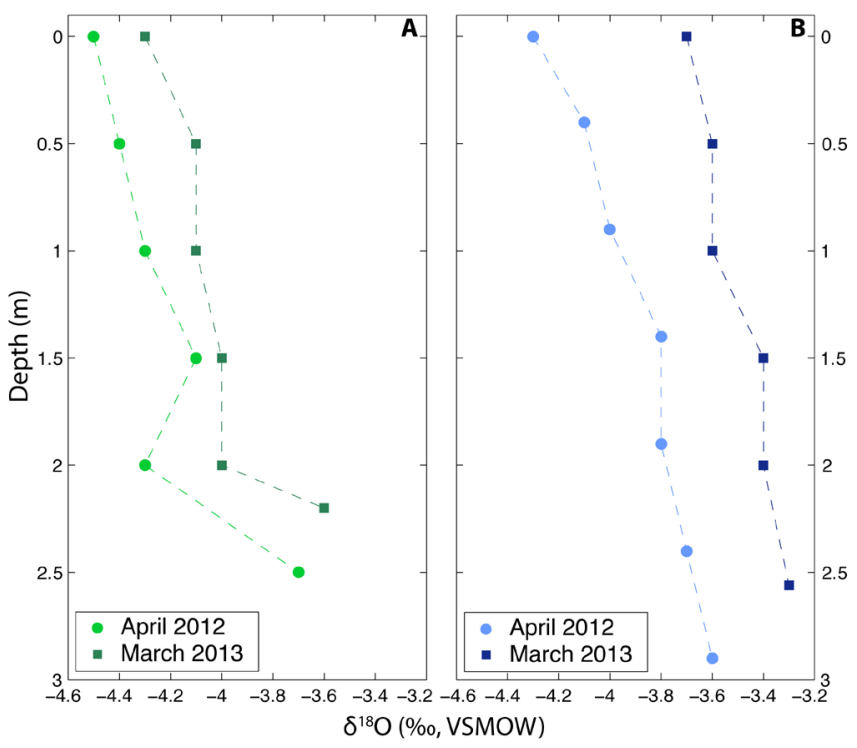

Fig. 3. The $\delta^{18} \mathrm{O}$ values of water from Vallgornera (A) and Drac (B).

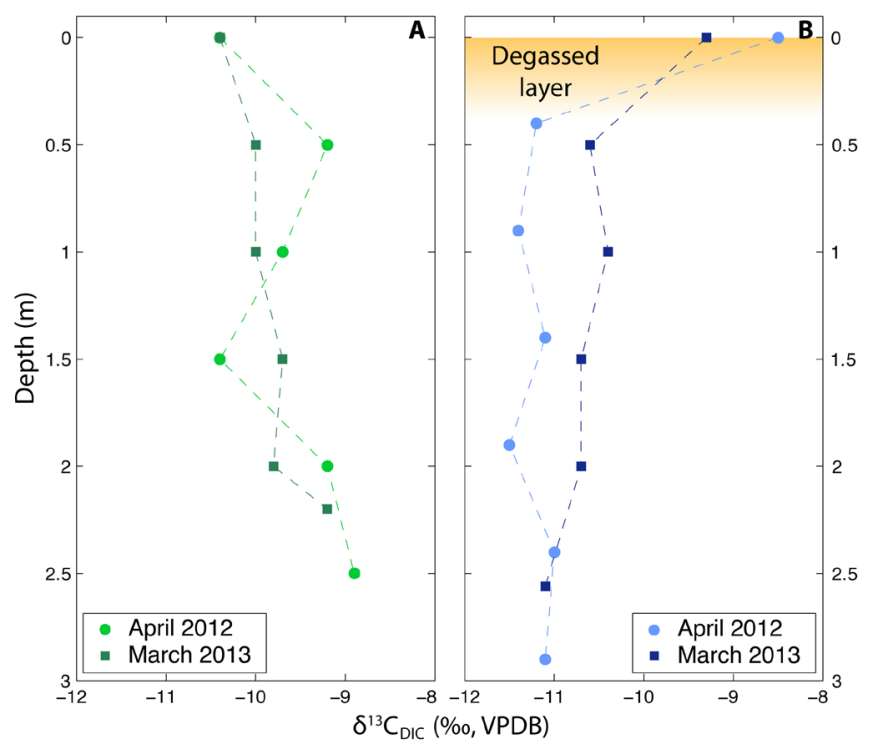

Fig. 4. $\delta^{13} C_{D I C}$ values of water from Vallgornera (A) and Drac (B).

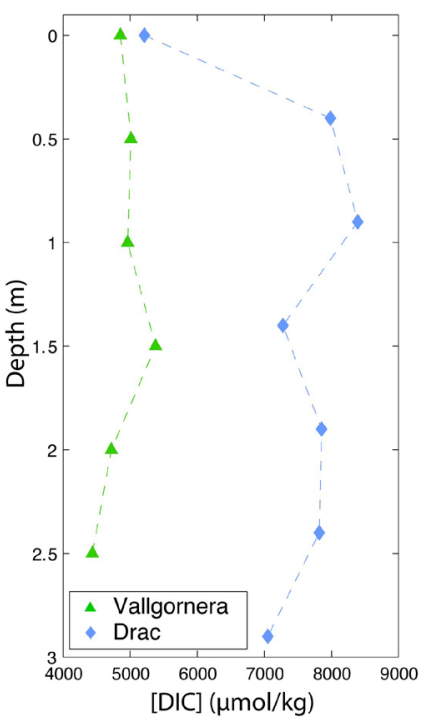

Fig. 5. [DIC] of water from Vallgornera and Drac in April 2012.

The plot of $\delta^{13} \mathrm{C}_{\text {DIC }}$ and [DIC] shows that the Vallgornera samples group distinctly with lower [DIC] and more positive $\delta^{13} \mathrm{C}_{\text {DIC }}$ than Drac (Fig. 6). A notable exception is the surface value from Drac, the most positive value of the dataset, which does not group with the deeper water samples from that cave.

\section{$\mathrm{pCO}_{2}$ in cave air and water}

For each sample obtained, air $\mathrm{pCO}_{2}$ is higher in Vallgornera (typically two times) than in Drac (Fig. 7A, Table 2). Over the short time period investigated, a distinct trend (part of a seasonal signal, as discussed in a forthcoming paper) is evident in both caves, with the highest values observed in October 2012 and decreasing throughout the monitoring period.

Water $p \mathrm{CO}_{2}$ generally displays the same decreasing trend as air $p \mathrm{CO}_{2}$ throughout the monitoring period (Table 2). Water $p \mathrm{CO}_{2}$ is always greater than air $p \mathrm{CO}_{2}$, which implies that a variable disparity between the water and the cave atmosphere is maintained over the monitoring period in both caves. The cave air $p \mathrm{CO}_{2}$ was subtracted from the surface water $\mathrm{pCO}_{2}$ for each corresponding month 


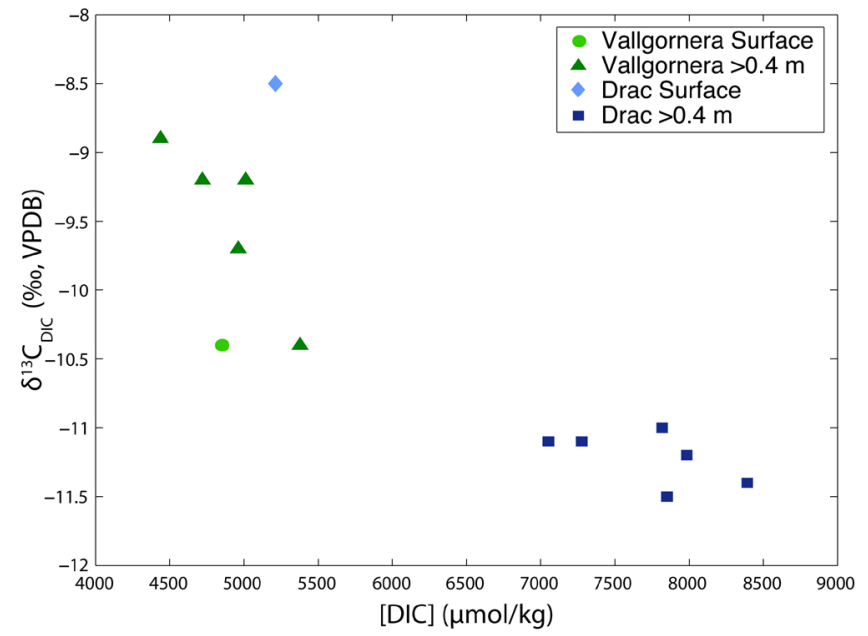

Fig. 6. $[\mathrm{DIC}]$ and $\delta^{13} \mathrm{C}_{\mathrm{DIC}}$ of water from the April 2012 profiles from Vallgornera and Drac.

to obtain the $\mathrm{CO}_{2}$ (aq-atm) difference (Fig. 7B). While there is no consistent trend over the monitoring period, samples for Drac display a higher $\mathrm{CO}_{2}$ (aq-atm) disparity between the water and air, compared to Vallgornera, which is generally lower.

\section{Saturation state of cave water}

Water samples collected during monthly site visits suggest that groundwater in both caves is typically below saturation with respect to both calcite and aragonite (Table 2). Only one $\mathrm{SI}_{\text {Calcite }}$ value from Vallgornera and two from Drac indicate that the water was supersaturated with respect to calcite (Fig. 8A). All samples for which $\mathrm{SI}_{\text {Aragonite }}$ was calculated are undersaturated (Fig. 8B).

\section{Elemental ratios in cave water}

Concentrations of $\mathrm{Mg}$, $\mathrm{Sr}$, and $\mathrm{Ba}$ are higher in Drac than in Vallgornera for every monthly sample except for October 2012. Ca and Mg have percent errors of 1.4 and $2.6 \%$, respectively, whereas Sr and Ba are much higher (5.7 and 5.3\%, respectively; Table 3). However, when considering $\mathrm{Mg}: \mathrm{Ca}, \mathrm{Sr}: \mathrm{Ca}, \mathrm{Ba} \mathrm{Ca}$, and $\mathrm{Sr}: \mathrm{Mg}$ ratios, these are consistently higher in Vallgornera than Drac (Fig. 9A-D).
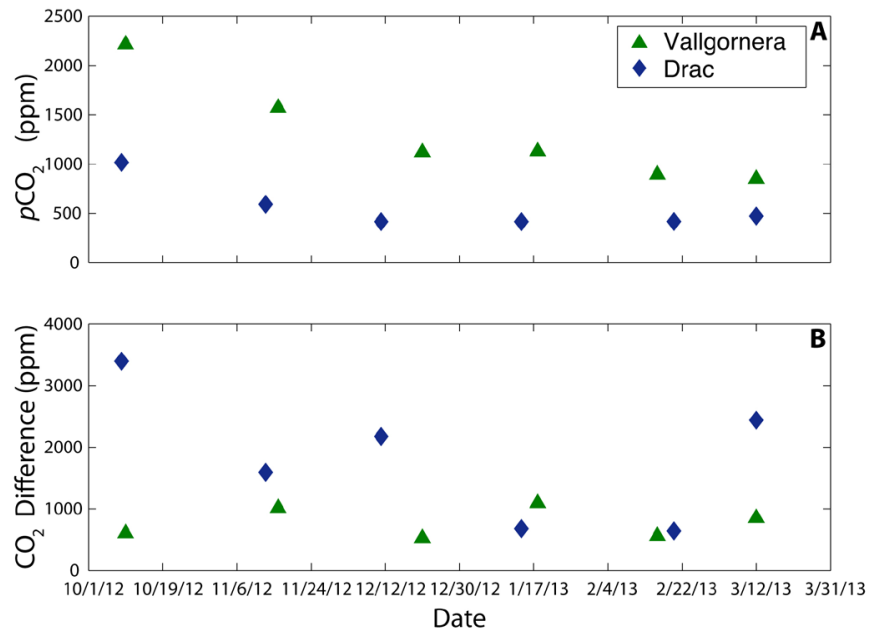

Fig. 7. Cave air $p \mathrm{CO}_{2}$ corresponding to the monthly surface water collection dates (A). Cave water $p \mathrm{CO}_{2}$ was calculated using water temperature, $\mathrm{pH}$, total alkalinity, and air $p \mathrm{CO}_{2}$. The $\mathrm{CO}_{2}$ difference (B) was calculated by subtracting the $\mathrm{pCO}_{2}$ of the cave water from the cave air.

\section{DISCUSSION}

Percolating meteoric water mixes with the marine groundwater flooding the cave passages to create a brackish solution, which is confirmed by both salinity and $\delta^{18} \mathrm{O}$ values (Table 1 ). The salinity of infiltrating meteoric water is close to zero, and the amount-weighted annual average $\delta^{18} \mathrm{O}$ of precipitation in Palma de Mallorca is $-5.6 \%$ (Araguas-Araguas \& Diaz Teijeiro, 2005), while the salinity of Mediterranean seawater is approximately $37 \mathrm{PSU}$ and its $\delta^{18} \mathrm{O}$ is $1.5-1.6 \%$ in samples along Mallorca's coast. Indeed, the lowest salinity and most negative $\delta^{18} \mathrm{O}$ values were detected at the water surface in each cave, which documents the increasing influence of seawater with depth, despite the fact that the nature of the connection to the Mediterranean Sea (matrix or conduit flow) is not known at either site.

Though a traditional Ghyben-Herzberg freshwater lens and complete halocline are absent in the investigated upper water column in both caves, the surface layer in Vallgornera is homogenous due to continuous flushing of seawater that mixes with percolating meteoric water (Fig. 2a). Further, it seems that water level fluctuations prevent the development

Table 2. Monthly water and air sample geochemical parameters. $\mathrm{pCO}_{2}, \mathrm{SI}_{\text {Calcite, }}$ and $\mathrm{SI}_{\text {Aragonite }}$ were calculated using $\mathrm{CO}_{2}$ calc.

\begin{tabular}{|c|c|c|c|c|c|c|c|c|c|c|c|c|c|}
\hline & Date & $\mathrm{pH}$ & $\begin{array}{c}\text { Temp } \\
\left({ }^{\circ} \mathrm{C}\right)\end{array}$ & $\begin{array}{c}\text { Salinity } \\
\text { (PSU) }\end{array}$ & $\begin{array}{c}\text { Total } \\
\text { Alkalinity } \\
\text { (mg/L) }\end{array}$ & $\begin{array}{l}\text { Total } \\
\text { Sulfate } \\
\text { (mg/L) }\end{array}$ & $\begin{array}{c}\text { Total } \\
\text { Hardness } \\
\text { (mg/L) }\end{array}$ & $\begin{array}{l}\text { Cave } \\
\text { Baro } \\
\text { Pres } \\
(\mathrm{hPa})\end{array}$ & $\begin{array}{l}p \mathrm{CO}_{2} \\
\text { Air } \\
(\mathrm{ppm})\end{array}$ & $\begin{array}{l}\text { Air } \\
\text { Temp } \\
{ }^{\circ} \mathrm{C}\end{array}$ & $\begin{array}{l}\mathrm{pCO}_{2} \\
\text { Water } \\
(\mathrm{ppm})\end{array}$ & $\mathrm{SI}_{\text {Calcite }}$ & $\mathrm{SI}_{\text {Aragonite }}$ \\
\hline \multirow{6}{*}{ 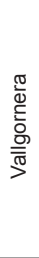 } & $10 / 10 / 12$ & 7.36 & 19.92 & 6.1 & 192 & 490 & 1,600 & $1,014.5$ & 2,214 & 19.7 & 2,818 & -0.41 & -0.66 \\
\hline & $11 / 16 / 12$ & 7.45 & 19.79 & 5.9 & 216 & 434 & 1,540 & $1,019.3$ & 1,571 & 19.6 & 2,585 & -0.28 & -0.53 \\
\hline & $12 / 21 / 12$ & 7.70 & 19.72 & 6.11 & 250 & 425 & 1,480 & $1,018.0$ & 1,121 & 19.5 & 1,646 & 0.03 & -0.22 \\
\hline & $1 / 18 / 13$ & 7.5 & 19.66 & 6.28 & 212 & 417 & 1,410 & $1,005.4$ & 1,129 & 19.5 & 2,222 & -0.23 & -0.48 \\
\hline & $2 / 16 / 13$ & 7.66 & 19.50 & 5.97 & 200 & 496 & 1,580 & $1,022.7$ & 893 & 19.4 & 1,452 & -0.11 & -0.36 \\
\hline & $3 / 12 / 13$ & 7.55 & 19.51 & 6.49 & 184 & 549 & 1,480 & $1,005.7$ & 849 & 19.4 & 1,699 & -0.24 & -0.49 \\
\hline \multirow{6}{*}{$\begin{array}{l}\stackrel{0}{\pi} \\
\stackrel{\pi}{0}\end{array}$} & $10 / 9 / 12$ & 7.18 & 18.66 & 7.94 & 212 & 455 & 1,430 & $1,019.1$ & 1,017 & 18.6 & 4,414 & -0.50 & -0.75 \\
\hline & $11 / 13 / 12$ & 7.47 & 18.57 & 7.44 & 204 & 550 & 1,380 & $1,016.2$ & 591 & 18.6 & 2,185 & -0.25 & -0.50 \\
\hline & $12 / 11 / 12$ & 7.4 & 18.58 & 7.91 & 208 & 539 & 1,680 & $1,021.6$ & 416 & 18.7 & 2,591 & -0.30 & -0.54 \\
\hline & $1 / 14 / 13$ & 7.76 & 18.53 & 7.55 & 204 & 538 & 1,710 & $1,013.4$ & 417 & 18.6 & 1,095 & 0.03 & -0.21 \\
\hline & $2 / 20 / 13$ & 7.82 & 18.53 & 7.33 & 226 & 650 & 1,830 & $1,015.3$ & 418 & 18.7 & 1,059 & 0.13 & -0.12 \\
\hline & $3 / 12 / 13$ & 7.35 & 18.61 & 8.64 & 212 & 716 & 1,750 & $1,004.7$ & 473 & 18.6 & 2,912 & -0.32 & -0.56 \\
\hline
\end{tabular}



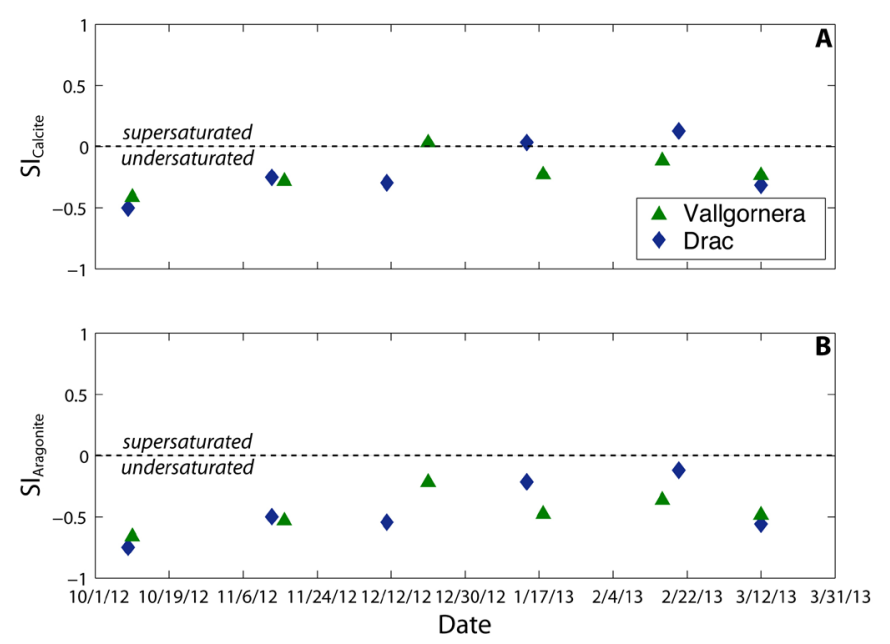

Fig. 8. Calculated SI for calcite (A) and aragonite (B) using CO2calc.

of a true freshwater lens at both sites as suggested by Mylroie and Vacher (1999) in other carbonate island caves, but do not preclude the stratification of brackish water in Vallgornera.

In both caves, samples in the March $2013 \delta^{18} \mathrm{O}$ profile are overall more positive compared to those of April 2012, while still trending toward higher values with depth. Combined, the isotope and salinity gradients indicate a decrease of meteoric water influence with depth, suggesting that the offset (and its magnitude) between the two profiles (Figs. 2 and 3) may be controlled by temporal variations of different hydrologic regimes (matrix vs. fracture flow, precipitation/infiltration amount).

Water bodies present within caves may act as both sources and sinks for $\mathrm{CO}_{2}$. The direction of $\mathrm{CO}_{2}$ diffusion depends on the magnitude of the $\mathrm{CO}_{2}$ (aq-atm) disparity and is site- and condition-specific. Baldini et al. (2006) report an example where cave water (a sump) acts as a $\mathrm{CO}_{2}$ sink. Palmer (2007) also discusses examples where $\mathrm{CO}_{2}$ is consumed by aqueous reactions during the dissolution of limestone. Conversely, $\mathrm{CO}_{2}$ respired by microbial consumption of organic matter within the water column (Pohlman, 2011) or by inorganic precipitation of $\mathrm{CaCO}_{3}$ at the air-water interface (Walvoord et al., 2005) may degas to the

Table 3. Monthly water sample elemental values. Percent error is reported for each element based on replicate analysis of standard reference material NIST $1640 a-1$.

\begin{tabular}{|c|c|c|c|c|c|}
\hline & Date & $\begin{array}{c}\mathrm{Mg} \\
(\mathrm{ppm})\end{array}$ & $\begin{array}{c}\mathrm{Ca} \\
\text { (ppm) }\end{array}$ & $\begin{array}{c}\mathrm{Sr} \\
(\mathrm{ppb})\end{array}$ & $\begin{array}{c}\mathrm{Ba} \\
(\mathrm{ppb})\end{array}$ \\
\hline \multirow{6}{*}{ 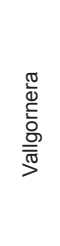 } & 10/10/12 & 232 & 194 & 1,828 & 27 \\
\hline & $11 / 16 / 12$ & 209 & 178 & 1,793 & 25 \\
\hline & $12 / 21 / 12$ & 205 & 173 & 1,650 & 24 \\
\hline & $1 / 18 / 13$ & 203 & 173 & 1,673 & 24 \\
\hline & $2 / 16 / 13$ & 196 & 169 & 1,731 & 24 \\
\hline & $3 / 12 / 13$ & 194 & 169 & 1,590 & 25 \\
\hline \multirow{6}{*}{ 苂 } & $10 / 9 / 12$ & 230 & 227 & 1,655 & 28 \\
\hline & $11 / 13 / 12$ & 245 & 243 & 1,870 & 28 \\
\hline & $12 / 11 / 12$ & 230 & 230 & 1,772 & 27 \\
\hline & $1 / 14 / 13$ & 240 & 237 & 1,724 & 28 \\
\hline & $2 / 20 / 13$ & 246 & 241 & 1,892 & 28 \\
\hline & $3 / 12 / 13$ & 294 & 278 & 2,123 & 31 \\
\hline Error & & $1.4 \%$ & $2.6 \%$ & $5.7 \%$ & $5.3 \%$ \\
\hline
\end{tabular}

cave atmosphere. The dataset presented in this study suggests that the cave water acts as a $\mathrm{CO}_{2}$ source in both caves, as evidenced by a positive $\mathrm{CO}_{2}$ (aq-atm) disparity (Fig. 7B). Isotopic fractionation occurs during degassing, thus enriching the surface of the water column in ${ }^{13} \mathrm{CO}_{2}$ (aq) (Vogel et al., 1970). The $\delta^{13} \mathrm{C}_{\mathrm{DIC}}$ data indicate that surface water with relatively high $\delta^{13} \mathrm{C}$ values (-8.5 and $-9.3 \%$ ) was less than 0.4 $\mathrm{m}$ thick in Drac (Fig. 4B). The [DIC] profile measured in April 2012 also shows that the uppermost layer in Drac was degassed, with a significantly lower [DIC] than deeper in the water column.

The $p \mathrm{CO}_{2}$ data for both Vallgornera and Drac show large fluctuations that result from ventilation during the winter months (Fig. 7A). In samples collected from October 2012 through March 2013, the highest values were recorded in October 2012, likely reflecting the end of the growing season and the peak of soil microbe respiration. Cooler and denser external air replaced cave air during the following months, increasing the rate of ventilation, and likely causing decreases in cave atmosphere $p \mathrm{CO}_{2}$ at both sites. The general value of cave air $\mathrm{pCO}_{2}$ is controlled by the efficiency of ventilation: more efficient ventilation in Drac, due to its configuration and two entrances, causes lower overall values than those recorded in Vallgornera, a single, nearly sealed entrance cave.

Though believed to be unidirectional, the observed amount of $\mathrm{CO}_{2}$ degassing is not strong enough to
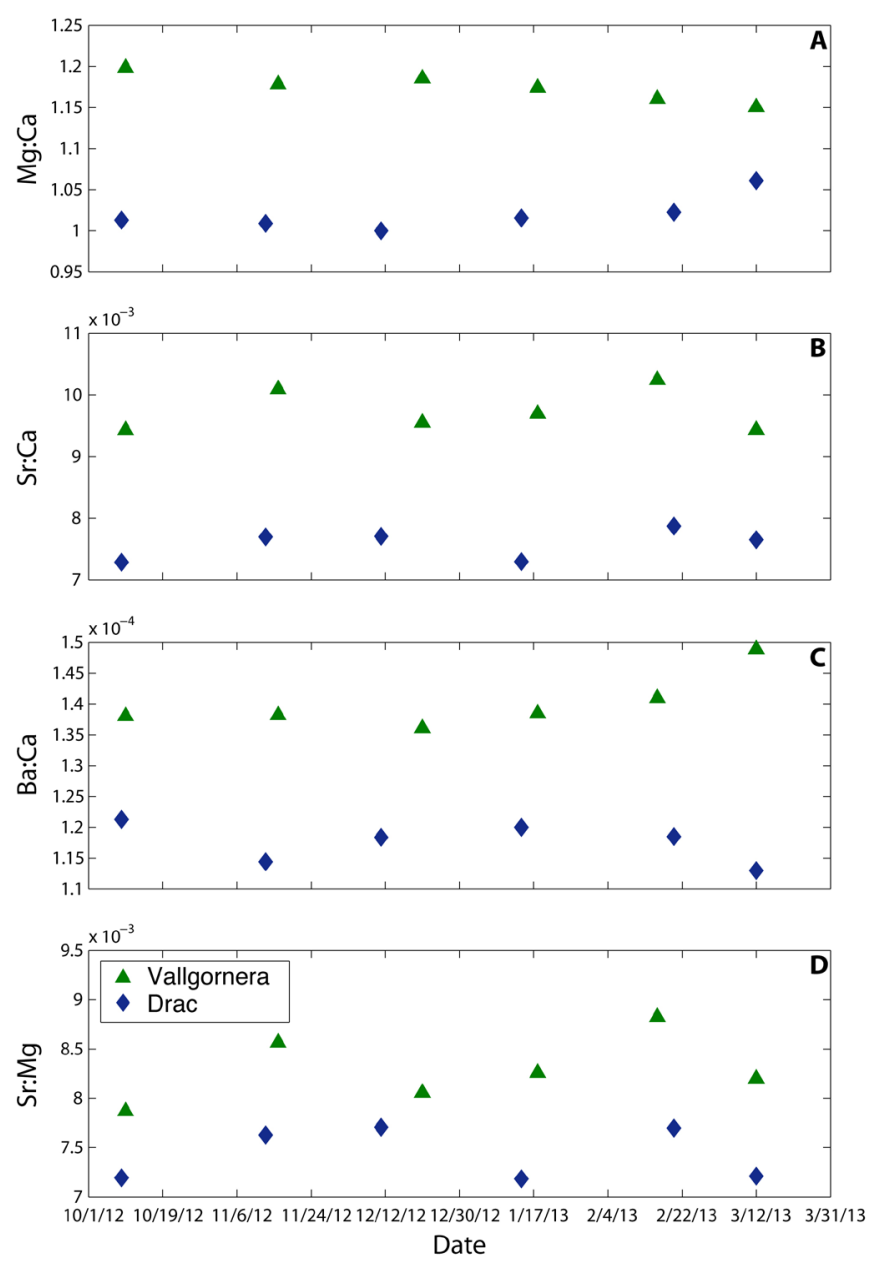

Fig. 9. Element ratios for the monthly surface water samples collected between October 2012 and March 2013; Mg:Ca (A), Sr:Ca (B), Ba:Ca (C), and Sr:Mg (D) are consistently higher in Vallgornera than Drac. 
cause extended periods of supersaturation with respect to carbonate minerals. Carbonate rafts, which precipitate as $\mathrm{CO}_{2}$ degasses at the water/air interface, are ephemeral in Drac and are rarely observed in Vallgornera. Positive $\mathrm{SI}_{\text {Calcite }}$ was only observed in one sample in Vallgornera and two in Drac, implying that over the observation period, the supersaturation state was not continuous.

Aragonite is believed to precipitate from supersaturated water under lower rates of $\mathrm{CO}_{2}$ degassing, whereas porous calcite precipitates under faster conditions (Frisia et al., 2000; 2002; Niedermayer et al., 2013). These conditions match the relatively less effective and more efficient ventilation patterns of Vallgornera and Drac, respectively. However, the limited occurrence of observed carbonate supersaturation in Drac and Vallgornera suggests that POS precipitation is presently inactive. For example, some studies suggest that a supersaturation threshold exists, below which nucleation of calcite crystals do not occur (Chafetz et al., 1991 and references therein). It may be possible that although supersaturation may have been occasionally reached in these sites, concentrations never exceeded the threshold required for nucleation.

$\mathrm{U} / \mathrm{Th}$ dates of an aragonite POS from Vallgornera indicate that its deposition ceased about 600 years ago (Tuccimei et al., 2009, 2010), though this date may reflect a maximum age because the sample was not taken from the outermost layer of the POS. As evidenced by abundant encrustation at the current water level, both investigated sites contain POS precipitated some time during the present sea level stand. However, the geochemical data reported in this study documents conditions generally not conducive to POS precipitation. This is further confirmed by a lack of measurable, permanent carbonate encrustations over artificial supports that were installed in May 2011. Yet, the current POS horizon does not display signs of corrosion, which suggests that while POS precipitation may be episodic (currently halted), the surface water is certainly not sufficiently undersaturated with respect to $\mathrm{CaCO}_{3}$ to corrode the existing POS.

While the data presented in this paper indicates that POS are not currently precipitating in either cave, the ion ratios observed in water samples align with established literature on the precipitation of aragonite instead of calcite. In vadose speleothems, the presence of the magnesium ion is the main control on the precipitation of aragonite (Thrailkill, 1971; Cabrol \& Coudray, 1982; McMillan et al., 2005; Frisia \& Borsato, 2010); this is commonly expressed as the ratio of $\mathrm{Mg}: \mathrm{Ca}$. Indeed, water samples from Vallgornera have an average $\mathrm{Mg}$ :Ca ratio of 1.17 while those from Drac averaged 1.02 (Fig. 9). Data aligns with experimental and field studies that reveal aragonite precipitation when $\mathrm{Mg}$ : Ca ratios are between 0.5 to over 4 (Fischbeck \& Müller, 1971; Frisia et al., 2002; De Choudens-Sánchez \& González, 2009; Niedermayr et al., 2013). While each study finds different $\mathrm{Mg}$ :Ca values within this range, it is likely that the precipitation of carbonate polymorphs depends not only on this ratio, but on a suite of other factors (acting alone or in combination) including trace elements, temperature, $\mathrm{CCO}_{2}, \mathrm{pH}$, salinity, $\mathrm{Mg}^{2+}$ and $\mathrm{Sr}^{2+}$ partition coefficients, mineralogy of the seed material, and activity of microorganisms (Ferrer et al., 1988; Zhong \& Mucci, 1989; Hill \& Forti, 1997 and references therein). To that end, the greater Sr:Ca, $\mathrm{Ba}: \mathrm{Ca}$, and $\mathrm{Sr}: \mathrm{Mg}$ ratios observed in this study suggest that higher relative abundances of $\mathrm{Sr}^{2+}$ and $\mathrm{Ba}^{2+}$ may also encourage aragonite precipitation and/or inhibit calcite precipitation (Lippmann, 1973; Terakado \& Taniguchi, 2006; Sunagawa et al., 2007).

Though seawater may contribute $\mathrm{Mg}, \mathrm{Sr}$, and $\mathrm{Ba}$ to the brackish water bodies in the two caves, the results of this indicate that salinity alone is not a suitable proxy for the presence of this suite of ions as suggested by Folk (1974). Consequently, interpreting the influence of salinity (only) on the mineralogy of carbonate encrustations is not straightforward. The occurrence of aragonite in Vallgornera, where lower salinity values were measured, may be triggered by the above-mentioned ions deriving from more intense bedrock weathering or a deep-water source that contains these ions. Alternatively, low salinity conditions caused by variations in the sulfate content may increase the $\mathrm{Mg}^{2+}$ partition coefficient in calcite, enhancing aragonite precipitation (Mucci \& Morse, 1983). However, because the solution is currently undersaturated, POS precipitation was not observed.

\section{CONCLUSION}

Unidirectional, though variable magnitude, $\mathrm{CO}_{2}$ degassing from the water to cave atmospheres was observed in this study, with $\mathrm{CO}_{2}$ (aq-atm) disparities ranging from 525 to $3,397 \mathrm{ppm}$. These findings are consistent with the conclusions of previous petrographic investigations of POS (and other speleothems) that the major control on carbonate deposition is the ability of $\mathrm{CO}_{2}$ to degas across the air-water interface (Pomar et al., 1976; Csoma et al., 2006).

The limited occurrences of aragonite POS in Mallorca indicate that specific conditions control its precipitation over calcite. In Vallgornera, aragonite POS are observed at the current sea level, whereas both calcite and aragonite are present in horizons precipitated at former lower or higher sea stands. Thus, although the micro-geochemical environment may be different in Vallgornera at present, allowing the precipitation of aragonite instead of calcite, results indicate that this process is currently episodic or halted. It is possible that slower/episodic $\mathrm{CO}_{2}$ degassing because of less efficient cave ventilation allows precipitation of dense aragonite in Vallgornera as compared to other caves on Mallorca. Alternatively, in caves that have more efficient exchange of air with the atmosphere, $\mathrm{CO}_{2}$ degassing is constant and faster, resulting in the growth of more porous calcite POS, like those observed in Drac (Ginés et al., 2012).

Several studies document that $\mathrm{Mg}, \mathrm{Sr}$, and $\mathrm{Ba}$, contributed from seawater, inhibit precipitation of calcite or enhance precipitation of aragonite. Therefore, it may be appropriate to assume that salinity (via activity 
coefficients) may be considered an adequate proxy for the relative abundance of these various ions. Furthermore, numerous field studies relating to beachrock cement and ooids suggest that salinity variations may control the mineralogy of the carbonate precipitates. The work of Zhong \& Mucci (1989), however, refutes this hypothesis, concluding that the partition coefficient of $\mathrm{Mg}^{2+}$ in calcite increases with decreasing salinity of the parent solution. Increasing presence of $\mathrm{Mg}^{2+}$ is thought to poison calcite crystal growth, allowing aragonite to precipitate. This study of two caves in Mallorca aligns with the findings of Zhong \& Mucci's (1989) showing aragonite POS observed in a lower-salinity environment. The ions have higher relative abundances in Vallgornera than Drac, and may be contributed by higher/more intense bedrock weathering or deep groundwater flow; further work is required to shed light over the entire aragonite/calcite precipitation process within the particular Mallorcan cave environment.

\section{ACKNOWLEDGEMENTS}

This material is based upon work supported by the National Science Foundation under grant AGS1103108 to BPO, the MICINN project, CGL201018616 from the Spanish Government to JJF, and Geological Society of America Graduate Student and National Speleological Society Research Grants to LMB. We express gratitude to the administration of Coves del Drac (Porto Cristo), who facilitates our research in the cave. Dr. James Garey is thanked for his insight and assistance during the April 2012 site visits. The authors appreciate Jessica Wilson's analytical assistance. Emily Jackson and Laura del Valle Villalonga are thanked for helping with the March 2013 fieldwork. Three anonymous reviewers are also thanked for offering constructive criticism that greatly improved this manuscript.

\section{REFERENCES}

Araguas-Araguas L.J. \& Diaz Teijeiro M.F., 2005 - Isotope composition of precipitation and water vapour in the Iberian Peninsula: first results of the Spanish Network of Isotopes in Precipitation. In: International Atomic Energy Agency Isotopic composition of precipitation in the Mediterranean Basin in relation to air circulation patterns and climate. International Atomic Energy Agency: 173-190.

Baldini J.U.L., Baldini L.M., McDermott F. \& Clipson N., 2006 - Carbon dioxide sources, sinks, and spatial variability in shallow temperate zone caves: evidence from Ballynamintra Cave, Ireland. Journal of Cave and Karst Studies, 68: 4-11.

Berner R.A., 1975 - The role of magnesium in the crystal growth of calcite and aragonite in sea water. Geochimica et Cosmochimica Acta, 39: 489-504. http://dx.doi.org/10.1016/0016-7037(75)90102-7

Cabrol P. \& Coudray J., 1982 - Climatic fluctuations influence the genesis and diagenesis of carbonate speleothems in southwestern France. National Speleological Society Bulletin, 44: 112-117.

Chafetz H.S., Rush P.F. \& Utech N.M., 1991 Microenvironmental controls on mineralogy and habit of $\mathrm{CaCO}_{3}$ precipitates: an example from an active travertine system. Sedimentology, 38: 107-126.

http://dx.doi.org/10.1111/j.1365-3091.1991.tb01857.x
Csoma A.E., Goldstein R.H. \& Pomar L., 2006 Pleistocene speleothems of Mallorca; implications for palaeoclimate and carbonate diagenesis in mixing zones. Sedimentology, 53: 213-236.

http://dx.doi.org/10.1111/j.1365-3091.2005.00759.x

De Choudens-Sánchez V. \& González L.A., 2009 Calcite and aragonite precipitation under controlled instantaneous supersaturation: elucidating the role of $\mathrm{CaCO}_{3}$ saturation state and $\mathrm{Mg} / \mathrm{Ca}$ ratio on calcium carbonate polymorphism. Journal of Sedimentary Research, 79: 363-376. http://dx.doi.org/10.2110/jsr.2009.043

Dorale J.A., Onac B.P., Fornós J.J., Ginés J., Ginés A., Tuccimei P. \& Peate D.W., 2010 - Sea-level highstand 81,000 years ago in Mallorca. Science, 327: 860-863. http://dx.doi.org/10.1126/science.1181725

Fairchild I.J., Smith C.L., Baker A., Fuller L., Spötl C., Mattey D., McDermott F. \& E.I.M.F., 2006 Modification and preservation of environmental signals in speleothems. Earth-Science Reviews, 75: 105-153.

http://dx.doi.org/10.1016/j.earscirev.2005.08.003

Ferrer M.R., Quevedo-Sarmiento J., Rivadeneyra M.A., Bejar V., Delgado R. \& Ramos-Cormenzana A., 1988 - Calcium carbonate precipitation by two groups of moderately halophilic microorganisms at different temperatures and salt concentrations. Current Microbiology, 17: 221-227.

http://dx.doi.org/10.1007/BF01589456

Fischbeck R. \& Müller G., 1971 - Monohydrocalcite, hydromagnesite, nesquehonite, dolomite, aragonite, and calcite in speleothems of the Fränkische Schweiz, Western Germany. Contribution to Mineralogy and Petrology, 33: 87-92. http://dx.doi.org/10.1007/BF00386107

Folk R.L., 1974 - The natural history of crystalline calcium carbonate: effect of magnesium content and salinity. Journal of Sedimentary Petrology, 44: 40-53.

Frisia S. \& Borsato A., 2010 - Karst. In: AlonsoZarza A.M. \& Tanner L.H. (Eds.), Carbonates in continental settings: facies, environments, and processes. Amsterdam: Elsevier: Developments in Sedimentology, 6: 269-318.

Frisia S., Borsato A., Fairchild I.J. \& McDermott F., 2000 - Calcite fabrics, growth mechanisms, and environments of formation in speleothems from the Italian Alps and southwestern Ireland. Journal of Sedimentary Research, 70 (5): 1183-1196.

http://dx.doi.org/10.1306/022900701183

Frisia S., Borsato A., Fairchild I.J., McDermott F. \& Selmo E.M., 2002 - Aragonite-calcite relationships in speleothems (Grotte de Clamouse, France): environment, fabrics, and carbonate geochemistry. Journal of Sedimentary Research, 72: 687-699.

http://dx.doi.org/10.1306/020702720687

Ginés A. \& Ginés J., 1972 - Consideraciones sobre los mecanismos de fosilización de la Cova de Sa Bassa Blanca y su paralelismo con las formaciones marinas del Cuaternario: II Congreso Nacional de Espeleología, Oviedo, p. 11-28.

Ginés A. \& Ginés J., 2007 - Eogenetic karst, glacioeustatic cave pools and anchialine environments on Mallorca Island: a discussion of coastal speleogenesis. International Journal of Speleology, 36 (2): 57-67. http://dx.doi.org/10.5038/1827-806X.36.2.1

Ginés J. \& Ginés A., 2011 - Les coves turístiques de les Illes Balears: antecedents $i$ estat de la qüestió. Endins, 35: 333-344. 
Ginés J., Ginés A., Fornós J.J., Tuccimei P., Onac B.P. \& Gràcia F., 2012 - Phreatic overgrowths on speleothems (POS) from Mallorca, Spain: updating forty years of research. In: Ginés A., Ginés J., Gómez-Pujol L., Onac B.P. \& Fornós J.J. (Eds.), Mallorca: a Mediterranean benchmark for Quaternary studies. Palma de Mallorca: Monografies de la Societat d'Història Natural de les Balears: 111-146.

Ginés J., Fornós J.J., Ginés A., Merino A. \& Gràcia F., 2014 - Geologic constraints and speleogenesis of Cova des Pas de Vallgornera, a complex coastal cave from Mallorca Island (Western Mediterranean). International Journal of Speleology, 43 (2): 105-124. http://dx.doi.org/10.5038/1827-806X.43.2.2

Gómez-Pujol L., Orfila A., Cañellas B., Alvarez-Ellacuria A., Méndez F.J., Medina R. \& Tintoré, J., 2007 - Morphodynamic classification of sandy beaches in low energetic marine environment. Marine Geology, 242: 235-246. http://dx.doi.org/10.1016/j.margeo.2007.03.008

Gràcia F., Fornós J.J. \& Clamor B., 2007 - Cavitats costaneres de les Balears generades a la zona de mescal, amb importants continuacions subaquàtiques. In: Pons G.X. \& Vicens D. (Eds.), Geomorfologia litoral $i$ Quaternari. Homenatge a Joan Cuerda Barceló. Palma de Mallorca: Monografies de la Societat d'Història Natural de les Balears: 299-352.

Gràcia F., Clamor B., Gamundí P. \& Fornós J.J., 2011a - Morfologies de corrosió de la zona de mescal a les cavitats subaquàtiques de la franja litoral del Llevant $i$ Migjorn de Mallorca. Endins, 35: 133-146.

Gràcia F., Clamor B., Gamundi P., Fornós J.J. \& Watkinson P., 2011b - Cavitats subaquàtiques de la franja litoral de Mallorca. Endins, 35: 103-132.

Guijarro J.A., 1995 - Bioclimatic aspects of karst in Mallorca. Endins, 20: 17-26.

Hill C.A. \& Forti P., 1997 - Cave minerals of the world $\left(2^{\text {nd }}\right.$ ed). Huntsville: National Speleological Society, 463 p.

Lippmann F., 1973 - Sedimentary Carbonate Minerals. Springer-Verlag, Berlin, 229 p.

http://dx.doi.org/10.1007/978-3-642-65474-9

Martin J.B., Gulley J. \& Spellman P., 2012 - Tidal pumping of water between Bahamian blue holes, aquifers, and the ocean. Journal of Hydrology, 416-417: 28-38. http://dx.doi.org/10.1016/j.jhydrol.2011.11.033

McMillan E.A., Fairchild I.J., Frisia S., Borsato A. \& McDermott, F., 2005 - Annual trace element cycles in calcite-aragonite speleothems: evidence of drought in the western Mediterranean 1200-1100 yr BP. Journal of Quaternary Science, 20 (5): 423-433.

http://dx.doi.org/10.1002/jqs.943

Merino A., Mulet A., Mulet G., Croix A., Kristofersson A., Gràcia F., Ginés J. \& Fornós J.J., 2011 - La Cova des Pas de Vallgornera (Llucmajor, Mallorca). La cavitat de major desenvolupament de les Illes Balears. Endins, 35: $147-164$.

Merino A., Mulet A., Mulet G., Croix A., Kristofersson A., Gràcia F. \& Perelló M.A. - Cova des Pas de Vallgornera (Mallorca, Spain): history of exploration and cave description. International Journal of Speleology, 43 (2): 95-104. http://dx.doi.org/10.5038/1827-806X.43.2.1

Millero F.J., Feistel R., Wright D.G. \& McDougall T.J., 2008 - The composition of Standard Seawater and the definition of the Reference-Composition Salinity Scale. Deep-Sea Research, I 55: 50-72.

http://dx.doi.org/10.1016/j.dsr.2007.10.001

Mucci A. \& Morse, J.W., 1983 - The incorporation of $\mathrm{Mg}^{2+}$ and $\mathrm{Sr}^{2+}$ into calcite overgrowths: influences of growth rate and solution composition. Geochimica et Cosmochimica Acta, 47: 217-233.

http://dx.doi.org/10.1016/0016-7037(83)90135-7
Mylroie J.E. \& Vacher H.L., 1999 - A conceptual view of carbonate island karst. In: Palmer A.N., Palmer M.V. \& Sasowsky I.D. (Eds.), Karst modeling. Charlottesville: Karst Waters Institute: 48-57.

Niedermayr A., Köhler S.J. \& Dietzel M., 2013 - Impacts of aqueous carbonate accumulation rate, magnesium and polyaspartic acid on calcium carbonate formation $\left(6-40^{\circ} \mathrm{C}\right)$. Chemical Geology, 340: 105-120.

http://dx.doi.org/10.1016/j.chemgeo.2012.12.014

Palmer A.N., 2007 - Cave Geology. Cave Books, Dayton, Ohio, $454 \mathrm{p}$.

Pohlman J.W., 2011 - The biogeochemistry of anchialine caves: progress and possibilities. Hydrobiologia, 677: 3351. http://dx.doi.org/10.1007/s 10750-011-0624-5

Pomar L., Ginés A. \& Fontarnau R., 1976 - Las cristalizaciones freaticas. Endins, 3: 3-25.

Pomar L., Ginés A. \& Ginés J., 1979 - Morfología, estructura y origen de los espeleotemas epiacuáticos. Endins, 5-6: 3-17.

Révész K.M. \& Doctor D.H., 2014 - Automated determination of the stable isotopic composition $\left(\delta^{13} C\right)$ of total dissolved inorganic carbon (DIC) and total nonpurgeable dissolved organic carbon (DOC) in aqueous samples: RSIL lab codes 1851 and 1852. In: U.S. Geological Survey Techniques and Methods, book 10, chap. C2O, 38 p.

http://dx.doi.org/10.3133/tm10C20

Robbins L.L., Hansen M.E., Kleypas J.A. \& Meylan S.C., 2010 - CO2calc: a user-friendly seawater carbon calculator for Windows, Mac OS X, and iOS (iPhone). U.S. Geological Survey Open-File Report 2010-1280: 17 p.

Robledo P.A. \& Durán J.J., 2010 - Evolución del turismo subterráneo en las Islas Baleares y su papel en el modelo turistico. In: Durán J.J. \& Carrasco F. (Eds.), Cuevas: patrimonio, naturaleza, cultura y turismo. Madrid: España Asociación de Cuevas Turísticas Españolas: 305-323.

Spötl C., Fairchild I.J. \& Tooth A.F., 2005 - Cave air control on dripwater geochemistry, Obir Caves (Austria): Implications for speleothem deposition in dynamically ventilated caves. Geochimica et Cosmochimica Acta, 69 (10): 2451-2468.

http://dx.doi.org/10.1016/j.gca.2004.12.009

Sunagawa I., Takahashi Y. \& Imai H., 2007 - Strontium and aragonite-calcite precipitation. Journal of Mineralogical and Petrological Sciences, 102: 174-181.

http://dx.doi.org/10.2465/jmps.060327a

Terakado Y. \& Taniguchi M., 2006 - Method for the study of trace element partitioning between calcium carbonate and aqueous solution: a test case for $\mathrm{Sr}$ and $\mathrm{Ba}$ incorporation into calcite. Geochemical Journal, 40: 161-170. http://dx.doi.org/10.2343/geochemj.40.161

Thrailkill J., 1971 - Carbonate deposition in Carlsbad Caverns. Journal of Geology, 79: 683-695.

http://dx.doi.org/10.1086/627698

Tuccimei P., Fornós J.J., Ginés A., Ginés J., Gràcia F. \& Mucedda M., 2007 - Sea level change at Capo Caccia (NW Sardinia) and Mallorca (Balearic Islands) during oxygen isotope stage $5 e$, based on Th/U datings of phreatic overgrowths on speleothems. In: Pons G.X. $\&$ Vicens D. (Eds.), Geomorfologia litoral $i$ Quaternari. Homenatge a Joan Cuerda Barceló. Palma de Mallorca: Monografies de la Societat d'Història Natural de les Balears: 121-135.

Tuccimei P., Soligo M., Fornós J.J., Ginés A., Ginés J., Onac B.P. \& Villa I.M., 2009 - Precipitation of phreatic overgrowths at the water table of meteoricmarine mixing zones in coastal cave systems; a useful tool in sea-level change reconstruction. In: White W.B. (Ed.), Proceedings of the $15^{\text {th }}$ International Congress of Speleology, 1: 554-560. 
Tuccimei P., Soligo M., Ginés J. Ginés A., Fornós J.J., Kramers J. \& Villa I.M., 2010 - Constraining Holocene sea-levels using U/Th ages of phreatic overgrowths on speleothems from coastal caves in Mallorca (western Mediterranean). Earth Surface Processes and Landforms, 35: 782-790.

Vogel J.C., Grootes P.M. \& Mook W.G., 1970 - Isotopic fractionation between gaseous and dissolved carbon dioxide. Zeitschrift für Physik, 230: 225-238.

http://dx.doi.org/10.1007/BF01394688
Walvoord M.A., Striegl R.G., Prudic D.E. \& Stonestrom D.A., 2005 - $\mathrm{CO}_{2}$ dynamics in the Amargosa Desert: fluxes and isotopic speciation in a deep unsaturated zone. Water Resources Research, 41: 1-15.

http://dx.doi.org/10.1029/2004WR003599

Zhong S. \& Mucci A., 1989 - Calcite and aragonite precipitation from seawater solutions of various salinities: precipitation rates and overgrowth composition. Chemical Geology, 78: 283-299.

http://dx.doi.org/10.1016/0009-2541(89)90064-8 